Acta vet. scand. $1964,5,362-369$.

From the Department of Animal Genetics, Nutrition and Hygiene, Royal Veterinary College, Stockholm.

\title{
SOMATIC CHROMOSOMES OF THE RABBIT
}

\author{
By \\ Ingemar Gustavsson
}

During the last few years, the methods for studying the chromosomes in the higher animals has undergone a marked improvement. With the introduction of tissue culturing, good and reliable methods have been obtained for the more detailed analysis of chromosomes. In human cytogenetics, very careful and exact studies have been carried out and thus the human karyotype is well known. A large number of anomalies, whose causes were until recently very obscure, have been traced to changes in the normal chromosome complement. Studies of the chromosomes in domestic animals with various disease conditions have also produced very valuable results. As the knowledge of the normal karyotype of a number of domestic animals is still incomplete however, clarification of this is necessary before further investigations can be undertaken.

This work has been carried out on short-term cultures of leucocytes. This method has considerable advantages, e. g. the simplicity of the collection of sample material and the high quality of the preparation which can be obtained. This method is also suitable for laboratories with simple equipment for tissue culture.

\section{MATERIAL AND METHOD}

Seven rabbits of the Swedish Landrace breed have been used. Tissue cultures were mainly made according to the method described by Moorhead et al. (1960). Bloodsamples from older 
animals were taken through an ear vein. In younger animals, the blood was taken directly from the heart after narcosis with ether. In order to obtain a good sedimentation the blood was mixed with dextran and placed in the refrigerator for about three hours. The relatively erythrocyte-free part of the supernatant was removed and centrifuged at 1500 r.p.m. for five minutes. The clear fluid was pipetted off and the cell deposit was carefully suspended in the nutritive medium Parker 199 containing $30 \%$ calf serum. Finally phytohaemagglutinin (Difco) was added, $0.1 \mathrm{ml}$. per $10 \mathrm{ml}$. medium and the cultures were incubated at $37^{\circ} \mathrm{C}$. On the third day colchicin was added in sufficient quantities to make a concentration of $10^{-7} \mathrm{M}$. In order to obtain a hypotonic solution, the cell suspension was mixed two hours later with three times its volume of distilled water. The cells were subsequently centrifuged down and fixed in Carnoy for twenty minutes. After centrifuging, the cells were carefully resuspended in fixing fluid. The suspension was then dropped on to an object glass which had been dipped in water. This was allowed to dry as quickly as possible without heating. The preparation was stained with acetoorcein $(2 \%$ orcein, $60 \%$ acetic acid) for twenty minutes and the chromosomes were studied in temporary mounts of Krönig cement. Mitoses with well distributed and distinct chromosomes were found, analysed and photographed, and then the chromosomes were arranged in homologous pairs. The squash technique with acetic acid plus hydrochloric acid as fixing fluid gave no divisions with clear chromosomes, probably due to the fact that the mitosing cells were filled with fat droplets (Nichols \& Levan, 1961).

\section{RESULTS}

Analyses of a large number of mitoses have shown a chromosome number of 44 (Figs. 1 and 2), a number previously given by a number of research workers including Painter (1926) and Melander (1956). The number of chromosomes was determined in 213 cells, of which about $90 \%$ contained 44 chromosomes. Deviations from this number are most likely due to cell rupture. Several chromosome pairs can be identified in preparations in which the chromosomes are well separated and distinct from each other. In many cases however, it was difficult to distinguish certain pairs. In order to obtain a more practical system of 


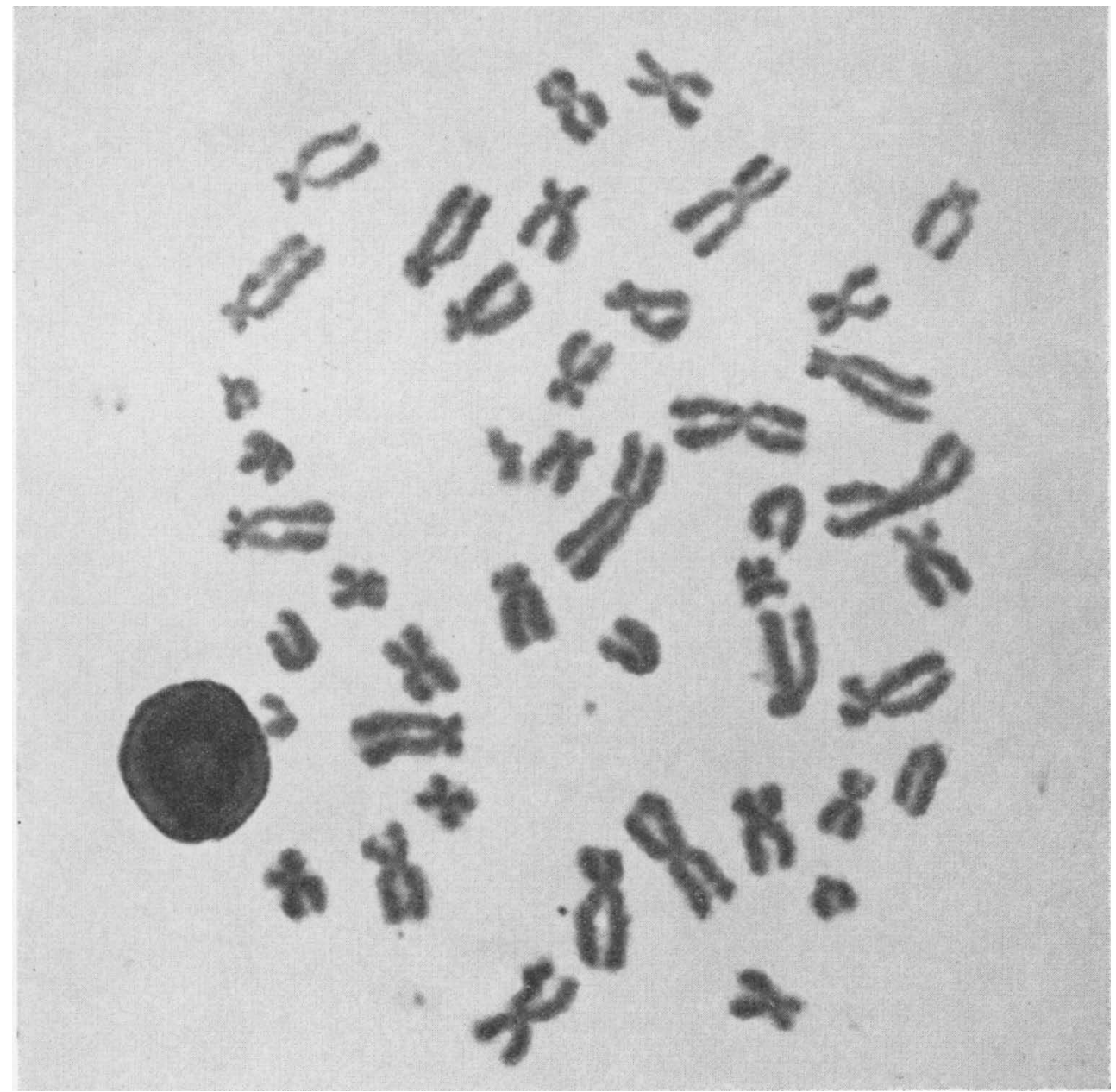

F i g. 1. Mitotic chromosomes in a leucocyte from a rabbit female. $-\times 2400$.

analysis, the chromosomes have been divided into groups according to similarity of appearance. Karyograms were constructed from apparently undamaged cells of each sex (Figs. 3 and 5). The karyotype may be described as follows.

Group I contains the largest chromosomes in the complement. They have median-submedian centromeres, but number 1 is longer than number 2.

Group II consists of a single pair with subterminal centromere. This pair is easy to identify. 


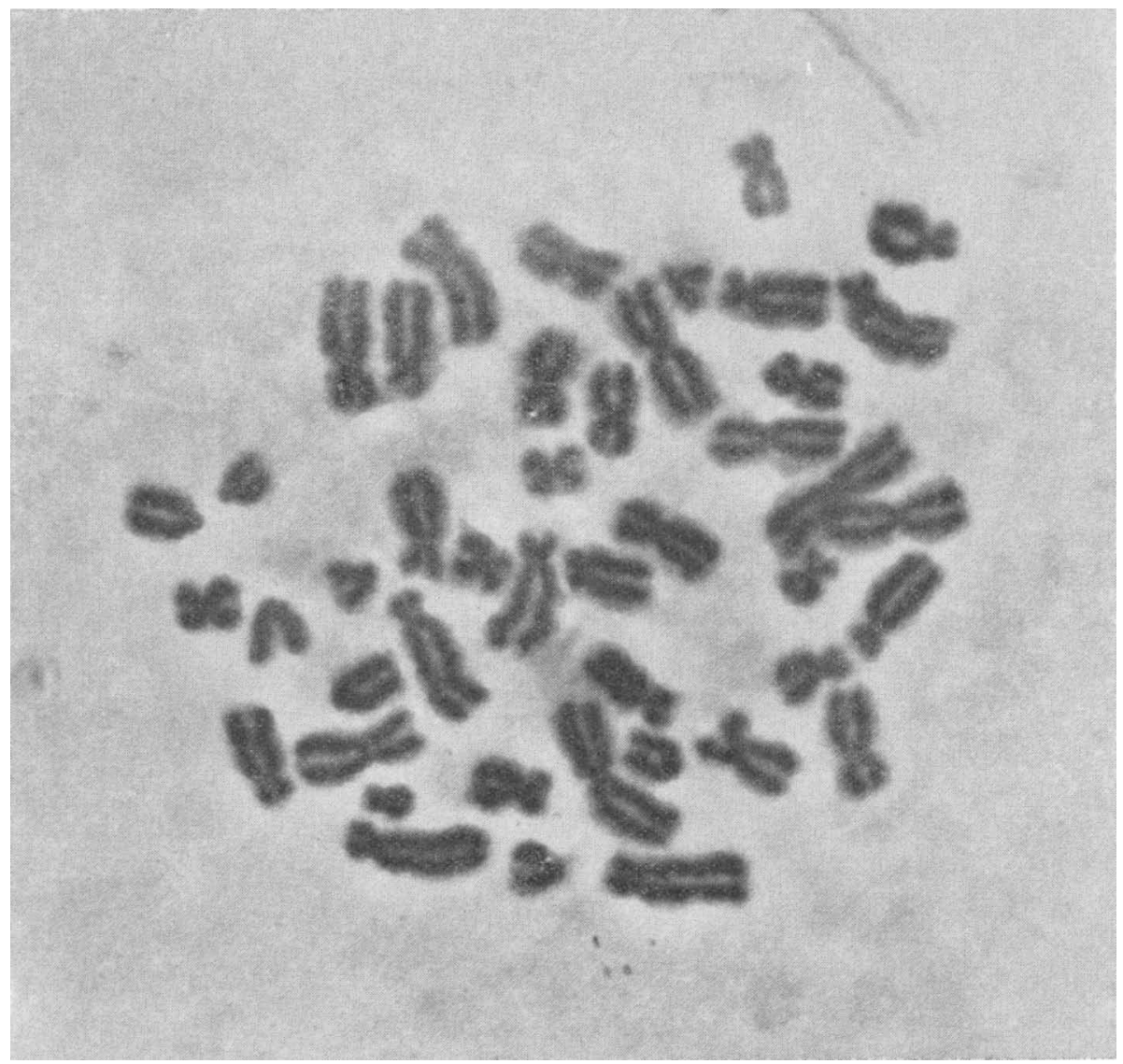

F i g. 2. Mitotic chromosomes in a leucocyte from a rabbit male. $-\times 2400$.

Chromosome 4 that makes up Group III shares with number 3 the distinction of being individually recognizable. Number 4 has a submedian centromere.

Group IV includes pairs 5-8. All members of this group have subterminal centromeres. There is a decline in size between the pairs.

Group V consists of pair $9-11$ including the $\mathrm{X}$ chromosome. The centromere position is median - submedian. Pair 9 is the largest of the group, and the distinction between 10 and the $X$ is questionable. Eleven differs from the $\mathrm{X}$ and 10 by a more central location of the centromere. 
$1-2$

3

4
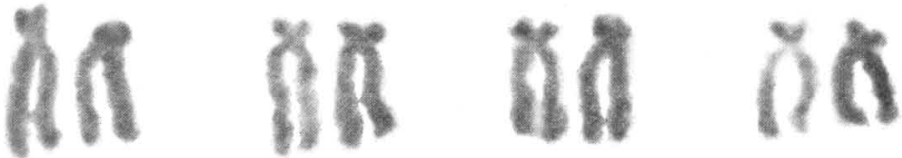

$5=$

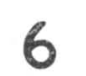

$-$

7
818

$-8$

ชิ่

กิ

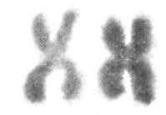

$9-10-x \times-11$
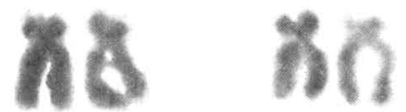

$12-13$

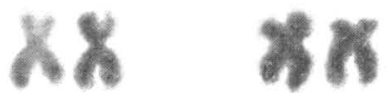

$14-15$

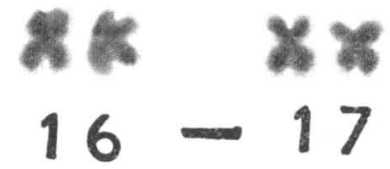

nan
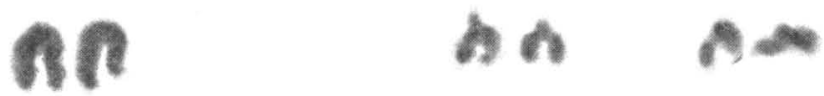

$18-19$

$20-21$

Fig. 3.

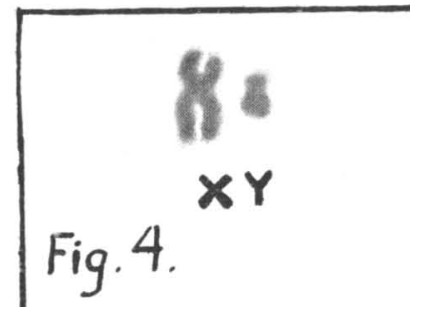

F i g. 3. Karyotype of a rabbit female (chromosomes taken from Fig. 1.). The chromosomes have been divided into groups according to similarity of appearance.

$\mathrm{Fig.}$ 4. The $\mathrm{X}$ and $\mathrm{Y}$ chromosomes of a rabbit male (taken from Fig. 2.). 


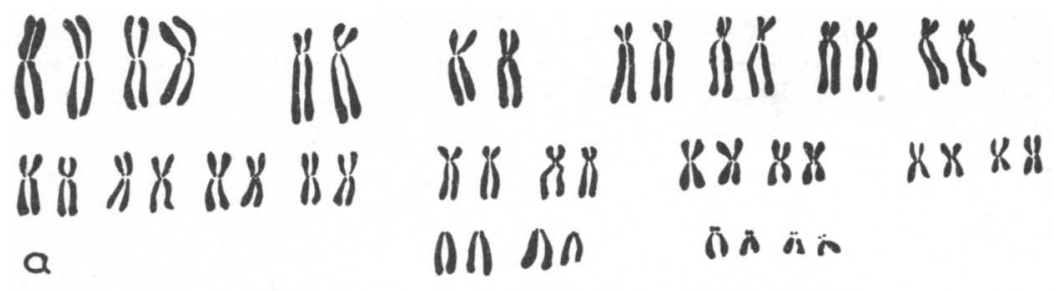

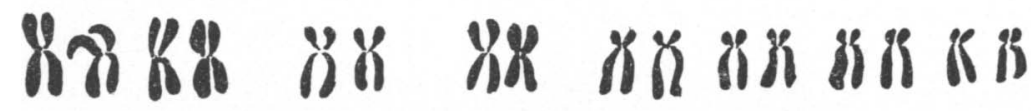

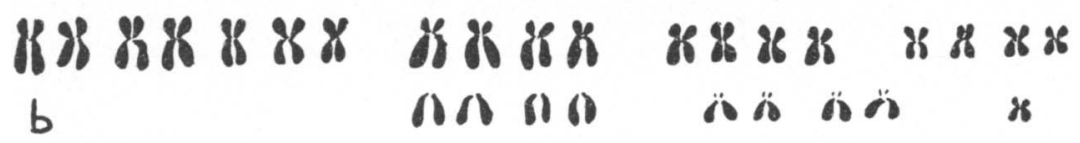

F i g. 5. Karyograms of the rabbit; a: female, b: male. The chromosomes have been divided into groups according to size and centromere position. Camera-lucida drawings. $-\times 1600$

Group VI includes pairs 12-13, which are similar to one another. They have subterminal centromeres and are very difficult to distinguish.

Pairs 14-15 constitute Group VII. The chromosomes have submedian centromeres and are very difficult to distinguish.

Group VIII contains pairs 16-17. The chromosomes are very similar to one another and have median centromeres.

Group IX contains pairs 18-19, both with terminal centromeres. The pairs are often hard to distinguish.

Group X contains pairs 20-21. The chromosomes have terminal or nearly terminal centromeres. The pairs are impossible to distinguish from each other.

Group XI consists of the $\mathrm{Y}$ chromosome, which is one of the smallest chromosomes in the complement. The chromosome has a submedian centromere and is always easy to identify.

A short description of the chromosome complement is given in Table 1 in which the terminology is based on the most obvious features of the mitotic chromosomes. 
T a b l e 1. Morphological analysis of the chromosomes of the rabbit.

\begin{tabular}{|c|c|c|}
\hline $\begin{array}{l}\text { Chro- } \\
\text { mosome } \\
\text { number }\end{array}$ & $\begin{array}{c}\text { Centromere } \\
\left.\text { position }^{1}\right)\end{array}$ & Observations \\
\hline $\begin{array}{l}1 \\
2\end{array}$ & $\begin{array}{l}\text { median - submedian } \\
-\end{array}$ & $\begin{array}{l}\text { Largest chromosomes in the comple- } \\
\text { ment. The pairs are hard to disting- } \\
\text { uish. }\end{array}$ \\
\hline 3 . & subterminal & Easy to identify. \\
\hline 4 & submedian & Easy to identify. \\
\hline $\begin{array}{l}5 \\
6 \\
7 \\
8\end{array}$ & subterminal & Decreasing length within the group. \\
\hline $\begin{array}{r}9 \\
10 \\
X \\
11\end{array}$ & $\begin{array}{l}\text { median }- \text { submedian } \\
- \text { - }\end{array}$ & Very difficult to distinguish the pairs. \\
\hline $\begin{array}{l}12 \\
13\end{array}$ & subterminal & Very difficult to distinguish the pairs. \\
\hline $\begin{array}{l}14 \\
15\end{array}$ & submedian & Pairs are hard to distinguish. \\
\hline $\begin{array}{l}16 \\
17\end{array}$ & median & Very difficult to distinguish the pairs. \\
\hline $\begin{array}{l}18 \\
19\end{array}$ & terminal & Difficult to distinguish the pairs. \\
\hline $\begin{array}{l}20 \\
21\end{array}$ & terminal & Impossible to distinguish the pairs. \\
\hline $\mathbf{Y}$ & submedian & Easy to identify. \\
\hline
\end{tabular}

1) median - submedian centromere; index long arm : short arm 1-1.9 subterminal centromere; arm index $2-4.9$ terminal or nearly terminal centromere; arm index 5 or more (Tjio \& Levan 1956).

\section{REFERENCES}

Melander, Y.: The chromosome complement of the rabbit. Hereditas 1956, 42, 432.

Moorhead, P. S., P. C. Nowell, W. J. Mellman, D. M. Battips \& D. A. Hungerford: Chromosome preparations of leucocytes cultured from human peripheral blood. Exp. Cell Res. 1960, 20, 613. 
Nichols, W. W. \& A. Levan: Chromosomes by the blood technique in various laboratory animals. Blood-bone marrow tissue culture and cell separation conference. Bethesda, Maryland, October $20-21,1961$.

Painter, T. S.: Studies in Mammalian spermatogenesis. VI. The chromosomes of the rabbit. J. Morph. 1926, 43, 1.

Tjio, J. H. \& A. Levan: The chromosome number of man. Hereditas 1956, 42, 1 .

\section{SUMMARY}

The number of chromosomes of the rabbit was determined at 44 , and both the $X$ and the $Y$ chromosomes have submedially situated centromeres. $\mathrm{X}$ is of medium size while $\mathrm{Y}$ is one of the smallest chromosomes of the complement. For practical purposes, the chromosomes have been divided into groups according to their appearance.

\section{ZUSAMMENFASSUNG}

Die somatischen Chromosomen des Kaninchens.

Die Anzahl der Chromosomen bei dem Kaninchen wurde zu 44 festgestellt. Sowohl das X-Chromosom als das Y-Chromosom haben ein submediales gelegten Centromer. Das X-Chromosom ist von Mittelgrösse und das Y-Chromosom ein von den kleinsten Chromosomen in dem Komplement. Aus praktischem Grund sind die Chromosompaaren von ihren Aussehen in Gruppen eingeteilt.

\section{SAMMANFATTNING \\ Kaninens somatiska kromosomer.}

Antalet kromosomer hos kanin bestämdes till 44, där både X- och Y-kromosomen har en submedialt belägen centromer. $X$ är av medelstorlek, medan $\mathrm{Y}$ är en av de minsta kromosomerna i komplementet. Av praktiska skäl har kromosomparen efter sitt utseende indelats i grupper. 